\title{
Vicious Circle of Public Conflicts, Conflict Behaviors, and Public Trust in South Korea*
}

\author{
Dong-Young Kim**
}

\begin{abstract}
Conflict and trust interact in a complex self-reinforcing vicious circle. With frequent, serious public conflicts, as well as stagnantly low level of trust in government, Korea may suffer from a vicious circle. This paper tests empirically whether Korea is in a vicious circle of public conflicts and public trust based on data from a questionnaire survey for 3,000 Korean citizens conducted during January and February 2016. The results show that individual experience of public conflicts significantly reduced the level of trust in government, and rights- and/ or power-based conflict behaviors of the individuals who experienced conflict lowered their level of trust in government more. As another link in a vicious circle, low level of public trust is believed to propel citizens to adopt more rights- and power-based approaches to conflict, which, in turn, may reduce the level of public trust in Korea. These results imply that the Korean government can build public trust through more effective conflict management.
\end{abstract}

Keywords: trust in government, public conflict, vicious circle, rights-based approach, power-based approach

\section{INTRODUCTION}

In the discourse of social capital, trust or distrust has been suggested as a core component in complex mechanisms of a self-reinforcing feedback loop, which can lead to either a virtuous or a vicious circle that includes cooperation or conflict (Fukuyama, 1995; Putnam, 1993). In a virtuous circle, interpersonal or social trust from civic engagement promotes cooperation among citizens, and cooperation promotes more trust, which in turn increases the quality of the governance (Putnam,

* This work was supported by Korea Development Institute and the Ministry of Education of the Republic of Korea and the National Research Foundation of Korea (NRF-2016S1A3A2924832).

** Dong-Young Kim is an associate professor at the Korea Development Institute School of Public Policy and Management. Email: dykim@kdischool.ac.kr.

Manuscript received October 16, 2017; out for review October 23, 2017; review completed November 21, 2017; accepted November 24, 2017.

The Korean Journal of Policy Studies, Vol. 32, No. 3 (2017), pp. 53-81.

(C) 2017 by the GSPA, Seoul National University 
1993, p. 117). In contrast, in a vicious circle, distrust or low level of trust among citizens prevents collaboration and also produces low levels of commitment and encourages the use of manipulative strategies and dishonest communication, which beget prolonged, frequent conflicts, feeding and encouraging further distrust (Ansell \& Gash, 2008). The consequence of the vicious circle is poor government (Putnam, 1993). As these circles are path dependent and sensitive to initial conditions in the past, their dynamic in a society hinges on the existence of long-term learning processes that people engage in over many decades (Mishler \& Rose, 2001).

This article draws on the concept of long-term self-reinforcing feedback loop of interpersonal trust at the microlevel of social relations to develop the idea of a relatively short-term self-reinforcing circle whereby a high trust in government on the part of citizens at the macrolevel of state-society relations leads greater collaborative governance, while a low trust leads to more public conflicts. The level of public trust in many countries is generally very low and deteriorating. Restoring it is a crucial task for sustainable, inclusive growth and a key condition for the successful adoption and implementation of much needed structural reforms (OECD, 2017). Specific policy-making situations in a democracy are likely to cause conflicts between the public and the government, particularly over the allocation of scarce resources, the setting of policy priorities or standards of various kinds (such as regulations regarding health, safety, and environmental protection), or moral disagreement on the contents of policies (OECD, 2010).

Given a background low level of public trust and inevitable conflicts around policy making, how a government manages such conflicts may affect which type of self-reinforcing circle, virtuous or vicious, prevails. Adopting mainly top-down adversarial modes of policy making in situations where lack of trust leads to frequent or serious conflicts between citizens and government agencies may decrease trust further, leaving the government and the public locked in a vicious circle. However, if the government can rebuild trust through an effective conflict management process, then, it may be possible to break out of the vicious circle and move into a virtuous circle.

South Korea (hereafter Korea) is a good case study for research that addresses the relationships between public conflicts, conflict management of the government, and the level of public trust. Trust in government in Korea has been dwindling. According to "Government at a Glance" (OECD, 2015), trust in the Korean government in 2014 was $34 \%$, which means that almost 7 out of 10 citizens expressed distrust in the Korean government, ranking Korea at 26th out of 41 OECD member countries. Which core drivers of public trust are more important in rebuilding it in a nation may differ. For example, exemplary delivery of public services in a country 
does not necessarily correlate with the level of trust in government (Bouckaert \& Van de Walle, 2003). While in some countries, the functioning of public services is the most important criterion of trust for the majority of citizens, the integrity of government may be more important to citizens as a whole in other countries. Thus, it is important to identify country-specific core-drivers of trust in order to rebuild public trust in any given country.

Considering the number of public conflicts in Korea since its democratization in 1987 and their social costs (Kim \& Cha, 2001; Han, 2014; Park, 2009; Park, 2010), it is reasonable to speculate that public conflicts may have affected the level of trust in Korea . According to studies on the severity of social conflict and the capacity across OECD member countries to manage such conflicts, Korea ranked 4th in severity in 2009 (Park, 2009) and ranked 27th among 34 OECD member countries in terms of social conflict management capacity in 2011 (Chung \& Ko, 2015). It is reasonable to suppose that frequent and prolonged clashing of interests and a lack of effective mechanisms to resolve conflicts in Korea has created animosity and a politics of distrust as well as distracted attention from efforts to work together to solve shared problems (Kim, 2014).

Does such a vicious circle characterize Korea? More specifically, how do conflicts that people experience with the government affect the level of trust in government in Korea? If conflicts with the government negatively affect the level of trust in government, then it is possible there is a vicious circle in Korea that has been created by low levels of public trust, public conflicts, and ineffective conflict management, which then leads to an even lower level of public trust. There is little empirical research globally or in Korea on this subject.

Using data from a survey conducted by KDI (Korea Development Institute) and the Organization for Economic Cooperation and Development (OECD) with 3,000 Korean citizens during January and February in 2016, this study explores how individuals' experience of public conflicts affects their level of trust in government in Korea, how their participation in public conflicts affects their level of trust in government, and how their level of trust in government might affect their conflict behavior in the future.

\section{PUBLIC CONFLICT AND PUBLIC TRUST}

To determine whether Korea is in a vicious circle of lack of trust and conflict, it is necessary to test two levels of causality: first, whether low levels of trust affect public conflict, and second, whether public conflicts determine levels of public trust. 
Although determination of such a loop requires sequential observations across time, this study overcomes the limitation of one-time survey questionnaire by using survey questions to ask individuals about their experiences of conflict in the past as well as about how they intend to manage conflict in the future. Accordingly, this article begins with the second causal relation between conflict and level of public trust first and then addresses the first one between public trust and conflict.

Can public conflict affect public trust? A substantial body of work has been developed around the topic of determinants of public trust globally since 1970s. However, still, there is a little clarity on the real origins of trust and distrust in government (Bouckaert \& Van de Walle, 2003). Also, a review of the literature discloses that little attention has been paid to public conflicts as a potential determinant of public trust or to the importance of conflict management in rebuilding public trust.

A major thread running through the literature is an "institutional" approach to public trust (Citrin, 1974; Hutchison \& Johnson, 2011) that assumes it is endogenous (Mishler \& Rose, 2001). Public trust on this view is a function of rational evaluations by citizens of the performance of public institutions and the actions of political leaders (Bovens \& Wille, 2008; Huseby, 2000). For example, when a government produces desired outcomes (Erber \& Lau, 1990; Przeworski et al., 1996) such as an economic boom (Feldman, 1983; Pharr \& Putnam, 2000) or services the citizens like (e.g., garbage collection) (Van de Walle \& Bouckaert, 2003), public trust ensues. Some researchers also argue that the process of policy making (Hibbing \& Theiss-Morse, 2001) influences public trust. If the public perceives the policy making process as fair (Alvarez \& Brehm, 1998; Fehr \& Schmidt, 1999; Kim, 2010), transparent (Hood, 2006), and participatory (Beierle \& Konisky, 2000), it is more likely to trust the government. Also, the institutional view maintains that public perceptions of the integrity of political leaders and government affect the level of public trust (Bovens, 2007; Pharr \& Putnam, 2000).

The issue of low public trust in Korea has been widely discussed, mainly in Korean publications that seek to identify what might affect public perceptions that lead to declining trust in government in Korea. Although, these studies largely agree that citizens' evaluations or perceptions of government performance in various sectors and policy-making processes are key determinants of public trust in Korea, there is no consensus on which types of government performances are affect citizens' trust in government the most. Park and Lee (2012) suggest that people who are more concerned about social problems, such as income inequality, economic downturns, and weak national security, tend to trust the government more, since they believe that government should be responsible for solving such problems. They also argue that the impact of social participation on citizens' trust in the government is negligible in 
Korea. Kim \& Yi (2009) argue that public perceptions of the national economy and economic policies as well as a widespread belief that the government was responsible for resolving economic crises were account more for the low level of trust in early days of Lee Myung-bak's administration (2008-13) than other political and social factors, such as political ideology, party identification, and class. However, Lee (2014) suggests that public satisfaction with social policies rather than economic policies is more statistically meaningful in explaining public trust in Korea. Assessing the Asia Barometer Survey of 2003, 2004, and 2006, Kim (2010) also finds that public trust in government in Korea is positively associated with factors such as controlling political corruption, preventing crime, and providing high-quality public services, a high standard of living, and environmental protections rather than government performance with respect to the national economy. Lee (2013) finds that despite satisfaction with national economic performance during Lee Myung-bak's administration, Korean citizens did not think the government succeeded with respect to maintaining political stability, ensuring a just society, and tackling human rights issues and that it is that dissatisfaction that accounts for the low level of public trust at that time.

Park \& Bae (2011) found in their national sample survey in Korea that fair treatment by the government (distributive fairness) and procedural fairness in policy making are stronger predictors of trust in government in Korea than relatively positive policy benefits and assessments of national economic conditions. Interestingly, absolutely positive policy benefits and assessments of personal economic condition, as well as embrace of political ideology reflecting preferences for policy outputs, had no or negligible effects on public trust in Korea. These findings imply that how government decides and implements policies is much more critical to public trust in Korea than what it produces and the consequences of its policies.

Lee (2013) explores the effect of civil servants' attitude toward work in Korea on trust in government and finds that the self-limiting behaviors of civil servants (such as relying on existing regulations, delaying necessary actions, and lowering goals) have a significantly negative impact on trust in government. Cho (2013) argues that public perception of the corruption of public officials is one of the major factors in distrust of government in Korea.

The differences in these findings on drivers of public trust in Korea may be explained partly by the fact that the researchers used different research methods and analytic tools and asked different survey questions of different samples. The political economic circumstances at the time the study was conducted may also affect outcomes, since there will be different styles of governance across different administrations, and there may be unexpected political or economic events. In other words, Korean citizens may possess a multidimensional conceptualization of the diverse 
drivers of public trust, but the specific drivers they name when surveyed may be dependent on their experiences in specific political economic contexts across different administrations. For example, Bae (2013) compares factors that affect citizens' attitudes toward different administrations and finds that while lack of professionalism was the factor that most negatively affected trust in during the Roh Moo-hyun administration, lack of transparency and deliberation were the factors that most negatively affected trust during the Lee Myung-bak administration.

Despite no explicit empirical research on the relationship between public conflict and public trust, it is reasonable to speculate that citizens' level of trust in government will be negatively affected by public conflicts they experience with the government pertaining to controversial policies, which is the first hypothesis of this study.

There is a distinction between public conflicts, perceptions of public conflicts, and experience of public conflicts. There is a school of thought that argues that the media plays negative role in mediating between government performance and public perceptions of it, particularly in connection with issues that are new, complex, and unrelated to existing cleavages and values (Newton, 2006; Zaller, 1996). Although the effect of media coverage on public trust is relatively temporary, emotional political cynicism or public distrust of the government and its political figures can be activated and fueled by strategic news coverage that treats every failure of government and politics as a crisis and focuses more on who wins and who loses and on a politician's motives and style than on collaboration and the contents of policies (Elchardus, 2002). Therefore, individuals' perception of public conflicts and the conflict management of the government can be critically and negatively affected by media coverage. In order to get a more accurate picture of the relationship between public conflicts and public trust, therefore, it is necessary to assess the perceptions or evaluations of individuals who directly experienced public conflicts for themselves as stakeholders. This study analyzes how such experiences affect individuals' trust in government and political institutions by comparing the levels of public trust of individuals who have experienced conflict with those who have not experienced conflict.

Testing the hypothesis that individual experience of conflict with the government will affect levels of public trust negatively requires defining what counts as an individual experience of public conflict. This study uses the term of "conflict" rather than "dispute." Although the two terms are often used interchangeably, some scholars draw a distinction between them. Costintino and Merchant (1996, pp. 4-5) define conflict as a fundamental disagreement between two parties, of which a dispute is one possible outcome. Other outcomes from conflict include conciliation, capitulation, or just lumping it (conflict avoidance). Yarn (1999) regards conflict as a state rather than a process. In a state of conflict, which may be latent (not acted upon yet) 
or manifest in the form of a dispute or disputing process, parties have opposing interests, values, or needs. Thus, "a conflict can exist without a dispute, but a dispute cannot exist without a conflict" (1999, p. 115). As this study intends to explore how the public in Korea behave when it and the government have a fundamental disagreement or opposing interests, values, or needs with respect to proposed public policies, the use of the term of "public conflict" is appropriate. Individual experience of public conflict, therefore, can be defined as a person's perception of a state of disagreement or opposing interests, values, or needs rather than as an experience of a specific manifest process, such as mass rally or ligation. In this definition, an individual's lumping it (conflict avoidance), as well as manifest process, are part of a state of conflict.

In order to articulate the definition of individual experience of public conflict, this study uses John Dewey (1927)'s definition of the public as a entity that is called into being by consequences arising from "some combined or conjoint action" that "expand beyond those directly engaged in producing" those consequences (p. 54) . And, Susskind and Field (1996) elaborate that the public becomes angry when it is adversely affected by implementation of public policies or projects that cause harm or accidents, or when it thinks it will be exposed to risk of being hurt by proposed policies or projects in the future.

Thus, direct individual experience of public conflicts as a stakeholder as an independent variable is defined in the survey questionnaire as "experience of harm to your personal or group's interests, values, or needs or experience of a risk of such harm by government policies or projects (e.g., large infrastructure projects, welfare policies, education policies, or urban planning, etc.) during the past three years." Survey respondents simply answered yes or no.

The many public conflicts in Korea and their severity are not the only potential source of lower levels of public trust; with the Korean political system itself may contribute to the problem. Kim and Yi (2013) argue that under a strong presidential political system, public trust in the government is highly likely to be related to public trust in the president. Thus, they imply that the working relationship between the president and the national assembly may affect the trust level in the government. Jeon, Kwon, and Jung (2013) also argue that confidence in the president is more influential than the public's positive evaluation of government policies in determining the trust level in the central government. Investigating the relationship between presidential leadership and government trust, Cho and Nam (2007) find that public evaluations of presidential competency in unification policies, diplomacy, and economy are much more important in increasing the level of trust in government. And while some policies, such as welfare policies and education policies, affect wide range of the general public and embroil politicians in conflicts in the national assem- 
bly, other policies or projects only have an impact on local residents and small number of stakeholders.

Out of 3,000 survey respondents, 397 people answered that they experienced various pubic conflicts between 2013 and 2015 pertaining to welfare policy, education policy, labor policy, mega-infrastructure projects, urban planning, and environmental policy in Korea (table 1). Survey respondents who experienced public conflicts also answered that central governments (49\%), local governments (41\%), and public corporations $(10 \%)$ should be held accountable and responsible for public conflicts.

Table 1. Public Policies or Projects Causing Citizens to Experience Conflict, 2013-15

\begin{tabular}{l|c}
\hline \multicolumn{1}{c|}{ Controversial Policies and Projects } & Frequencies \\
\hline welfare policy & $207(27 \%)$ \\
\hline education policy & $184(24 \%)$ \\
\hline labor policy & $107(14 \%)$ \\
\hline mega-infrastructure project & $99(13 \%)$ \\
\hline urban planning & $92(12 \%)$ \\
\hline environmental policy & $69(9 \%)$ \\
\hline other & $8(1 \%)$ \\
\hline Total & 766 \\
\hline
\end{tabular}

This leads us to the second hypothesis of this study, which is that people will react in different ways to individual experience of conflict with the government, which in turn will affect their level of public trust in various public institutions. For example, some people react to conflict by just lumping it (or do nothing). Others may participate in public hearings, sue the government, or join in a street demonstration.

Regarding conflict behaviors, Ury, Brett, and Goldberg (1988) suggest that people tend to adopt one of the three approaches to resolve a conflict: an interests-based approach, such as negotiation and mediation, a rights-based approach, such as litigation, and power-based approach, such as taking part in demonstrations and coalition building. They favor an interests-based approach, arguing that "reconciling different interests costs less and yields more satisfactory results than determining who is right, which in turn costs less and satisfies more than determining who is more powerful" (p. 4). 
The approach individual citizens adopt to handle their conflict with the government depends on the opportunity and venues that the government provides for conflict management. For example, if public agencies choose the mode of collaborative governance as an alternative to top-down adversarial modes of policy making and bring citizens and multiple stakeholders together to engage in consensus-oriented decision making in the process of conflict management (Ansell \& Gash, 2008), the levels of trust of the participants toward the government agencies as well as other participants may be directly influenced by the quality of the collaborative process. Thus, information as to how citizens reacted to a conflict with the government may provide hints about the conflict management mode of the government as well as about citizens' individual dispositions independent from government's performance. This also helps to formulate the third hypothesis in this study: rights- and power-based approaches to address public conflict with the government will affect the levels of public trust more negatively than other conflict approaches.

Returning to the causalities in a vicious circle of lack of trust and conflict, we can now consider the first one, the relation between level of trust and public conflict. The topic of trust and conflict has been studied in various contexts of interpersonal relations (Simpson, 2007), ethnic conflict (Dovidio et al., 2002), organizational relations (Mayer et al., 1995), social identity conflicts (Eidelson \& Eidelson, 2003), international group conflicts (Kelman, 2005), and collaborative governance (Weech-Maldonado $\&$ Merrill, 2000). This interdisciplinary literature widely recognizes that the levels of trust or distrust in a relationship definitively shapes emergent conflict dynamics (Lewicki \& Wiethoff, 2000) and that a lack of trust propels groups toward conflict and prevents them from collaborating (Honeyman et al., 2004). Honeyman, Goh, and Kelly (2004) suggest "distrust as one formidable obstacle between the two most polarized conflict groups “(p. 2).

However, another large body of literature suggests that trust building is possible, although quite difficult, even in conflict and that the ability to build trust is a crucial factor for conflict resolution in collaborative governance (Beierle \& Konisky, 2001; Imperial 2005; Murdock, Wiessner, \& Sexton 2005; Vangen \& Huxham, 2003; Weech-Maldonado \& Merrill, 2000). How to build trust in such an environment and how to sustain it during the collaborative process aimed at resolving a conflict are very important matters in practice (Kim, 2014). The possibility of building trust through effective conflict management implies that individual experience of public conflict does not necessarily lower the level of public trust. Despite the vast amount of literature on endogenous, institutional core drivers of public trust, there are few empirical studies that focus on public conflict and the way the conflict management of the government may affect the level of public trust in a country. 
A few studies focus on the relationship between conflict management and trust in Korea. Kim and Shim (2011) conducted a survey of residents who lived near where the government wanted to build a nuclear power plant to empirically test this relationship and found that increased transparency on the part of the government (by keeping the public fully informed about the plans for the proposed nuclear power plant, by ensuring that the new nuclear power plant would be safe, by compensating the community) may increase the level of trust in responsible public institutions and in turn the public's level of acceptance of the building of new plants or other facilities near their homes and hence reduce the amount of conflict over the siting process. In another case, Moon and Park (2014) consider a 2013 government policy to increase the price of tobacco, exploring how government competency in managing a conflict affects public trust and distrust in the government and also how the level of public trust and distrust influence publics' conflict behaviors. The survey of 193 Korean participants revealed that government competency in managing conflict and its procedural transparency in policy making affect public trust significantly.

Yang and Park (2007) explore whether stakeholder participation in government-led participatory mechanisms can increase the level of trust in the government by analyzing perceptions of doctors and pharmacists on the Ministry of Public Health in Korea. They find that stakeholders who participated in government-led participatory programs for public health policy making came to put more trust in the government because these programs indicated that the government officials were willing and able to listen and respond to stakeholders voice their interests and needs.

In order to test the impact of public trust on public conflict, this studies focuses on the conflict behavior of the public as an important aspect of public conflict. One of the survey questions asks, "if you are in a public conflict with the government (e.g., over large infrastructure projects, welfare policies, education policies, or urban planning, etc.), how do you address your concerns about the future?" This informs the fourth hypothesis of this study, which is that unless the government encourages citizens to participate in collaborative governance, a low level of trust in government on the part of citizens will drive them to choose a rights- or power-based approach rather than a interests-based negotiation, which may increase the frequency and severity of conflict.

Finally, a review of the literature helps to identify other variables that may affect public trust that this study uses as control variables. Some researchers suspect that a deeper process may underlie the change of levels of trust over time, given that public trust does not necessarily rebound in the face of better government performance (Dalton, 2004; Pharr \& Putnam, 2000; Van de Walle \& Bouckaert, 2003). This cultural approach to public trust suggests that it is exogenous rather than endogenous. That is, factors that are most relevant to public trust originate outside the political sphere and 
contribute to a steady erosion of public trust over time. In other words, citizens' evaluations of institutional performance, which inform how much trust they put in government, are conditioned by cultural values and beliefs that vary across nations (Dalton, 2004; Putnam, 1995). For example, the growth of democracy that has led to long-term changes in citizens' expectations and values and given rise to "critical citizens" among the upper social strata and the young who are less deferential to and more challenging of government authority may in part explain the decline of public trust in public institutions in advanced industrialized countries (Christensen \& Laegrieid, 2005; Dalton, 2004; Inglehart, 1999).

In Korea, women (Kim, 2009), younger generations (Kim, 2009), and the more educated who have a greater interest in politics (Cho, 2013) tend to distrust government more than men, older generations, and the less educated who have little interest in politics. However, Lee (2014) argues that better-educated people with high income tend to trust government more, since they tend to benefit more from government policies. Some scholars explore the impact of individual political ideologies on trust in government in Korea. Comparing trust levels during Roh Moo-hyun administration (more progressive government) and Lee Myung-bak's administration (more conservative government), Kum and Baek (2010) argue that people's political ideologies and beliefs affect the level of trust in government in Korea. While people with progressive leanings were more trustful of the Roh administration in 2007 than those with conservative leanings, people with conservative leanings were more trustful in Lee Myungbak's administration in 2009 and 2010. Thus, this study uses demographic variables such as gender, age, education, income, and political ideology, as control variables.

\section{DATAAND ANALYSIS}

From January 20 to February 22, in 2016, the Economic Information and Education Center (EIEC) of the Korea Development Institute (KDI) conducted a survey with 3,000 Korean nationals over 20 years old who were identified via stratified random sampling and interviewed face-to-face with a structured questionnaire. The sample represents the statistical characteristics of the general Korean population according to the sampling frame of the 2010 Korean census. The demographic variables used as control variables are processed as dummy variables, with exception of age to ensure a more accurate statistical analysis (table 2). 
Table 2. Control Variables

\begin{tabular}{|c|c|}
\hline Control Variables & Measurement \\
\hline Male & dummy (1: male, 0 : female) \\
\hline Age & numerical (more than 20 years old) \\
\hline Education ( $\leq$ Middle School) & $\begin{array}{l}\text { dummy (1: no education or the highest level of education is } \\
\text { elementary school or middle school) }\end{array}$ \\
\hline Education (High School) & dummy (1: the highest level of education is high school) \\
\hline Education (Vocational College) & dummy (1: the highest level of education is vocational college) \\
\hline Education ( $\geq$ University) & $\begin{array}{l}\text { dummy (1: the highest level of education is undergraduate } \\
\text { degree in four-year university or master's or doctoral degree) }\end{array}$ \\
\hline Income (Very Poor) & dummy (1: income less than 12 million) \\
\hline Income (Poor) & dummy (1: income between $12-24$ million) \\
\hline Income (Medium) & dummy (1: income between $¥ 24-60$ million) \\
\hline Income (Rich) & dummy (1: income more than $\$ 60$ million) \\
\hline Very Progressive & dummy (1: very progressive) \\
\hline Progressive & dummy (1: progressive) \\
\hline Neutral & dummy (1: neutral) \\
\hline Conservative & dummy (1: conservative) \\
\hline Very Conservative & dummy (1: very conservative) \\
\hline
\end{tabular}

\section{Impact of Experience of Public Conflict on the Level of Public Trust}

The survey question to test the hypothesis that individual experience of conflict with the government will affect levels of public trust negatively was "how much confidence do you have in the government in the broad sense (including central government, local governments, public enterprises, public institutions and all other kinds of public organizations) to act in the best interest of society?" Respondents were given the opportunity to rate their levels of trust on a 11-point scale, where 0 is no confidence and 10 is very confident (table 3 ). 
Table 3. Main Variables in Measuring Trust

\begin{tabular}{l|l}
\hline \multicolumn{1}{c|}{ Variables } & \multicolumn{1}{c}{ Measurement } \\
\hline $\begin{array}{l}\text { Dependent Variable } \\
\text { public trust (trust in } \\
\text { government) }\end{array}$ & $\begin{array}{l}\text { How much confidence do you have in the government in the } \\
\text { broad sense (including central government, local governments, } \\
\text { public enterprises, public institutions, and all other kinds of public } \\
\text { organizations) to act in the best interest of society? } \\
\text { (0: no confidence, 10: very confident) }\end{array}$ \\
$\begin{array}{l}\text { Independent Variable } \\
\text { direct experience of public } \\
\text { conflict as a stakeholder }\end{array}$ & $\begin{array}{l}\text { Have your interests or values ever been directly affected } \\
\text { negatively by government policies or projects, or do you expect } \\
\text { your interests or values will be affected negatively by government } \\
\text { policies or projects in the future? } \\
\text { dummy variable (1: yes, 0: no) }\end{array}$ \\
\hline
\end{tabular}

Table 4 shows descriptive statistics of public trust in Korea measured through the survey. The sample size is, as noted, 3,000, and 0 is not confident at all, while 10 is very confident.

Table 4. Descriptive Statistics of Public Trust in Korea

\begin{tabular}{l|c|c}
\hline \multirow{1}{*}{\multicolumn{1}{c|}{ Public Institutions }} & \multicolumn{2}{c}{ Public Trust } \\
\cline { 2 - 3 } & Mean & Standard Deviation \\
\hline government in a broad sense & 5.08 & 1.98 \\
central government & 5.04 & 2.00 \\
local government & 5.19 & 1.94 \\
national assembly & 4.03 & 2.12 \\
courts & 5.30 & 1.93 \\
public corporations & 5.43 & 1.85 \\
\hline
\end{tabular}

According to the answers to the question of conflict experience during the three years prior to taking the survey, the survey respondents can be categorized into two groups: people who have experienced public conflicts directly as stakeholders $(\mathrm{N}=$ $397)$ and people who did not experience public conflicts directly $(\mathrm{N}=2,603)$ during 2013 and 2015. Table 5 shows the demographic characteristics of the respondents. A comparison of the data of the group that had directly experienced public conflict experience and between the two groups suggests that middle-aged, progressive, more educated, relatively rich, male respondents experienced more conflicts than others. 
Table 5. Demographic Characteristics of Respondents

\begin{tabular}{|c|c|c|c|}
\hline \multirow[b]{2}{*}{ Variables } & \multicolumn{3}{|c|}{ Percentage (\%) } \\
\hline & 3,000 & $\begin{array}{l}\text { Citizens Who Experienced } \\
\text { Public Conflicts Directly as a } \\
\text { Stakeholder ( } \mathrm{N}=397)\end{array}$ & $\begin{array}{c}\text { Citizens Who Did Not } \\
\text { Experience Public Conflicts } \\
(\mathrm{N}=2,603)\end{array}$ \\
\hline $\begin{array}{l}\text { Age } \\
20 \mathrm{~s} \\
30 \mathrm{~s} \\
40 \mathrm{~s} \\
50 \mathrm{~s} \\
60 \text { and above }\end{array}$ & $\begin{array}{l}538 \\
636 \\
670 \\
536 \\
620 \\
\end{array}$ & $\begin{array}{c}71(13 \%) \\
99(16 \%) \\
122(18 \%) \\
63(12 \%) \\
42(7 \%)\end{array}$ & $\begin{array}{l}467(87 \%) \\
537(84 \%) \\
548(82 \%) \\
473(88 \%) \\
578(93 \%)\end{array}$ \\
\hline $\begin{array}{l}\text { Gender } \\
\text { Male } \\
\text { Female }\end{array}$ & $\begin{array}{l}1,467 \\
1,533\end{array}$ & $\begin{array}{l}218(15 \%) \\
179(12 \%)\end{array}$ & $\begin{array}{l}1249(85 \%) \\
1354(88 \%)\end{array}$ \\
\hline $\begin{array}{l}\text { Education } \\
\text { No Schooling } \\
\text { Elementary School } \\
\text { Middle School } \\
\text { High School } \\
\text { Vocational College } \\
\text { Four- Year University } \\
\text { master's degree } \\
\text { doctoral degree }\end{array}$ & $\begin{array}{c}8 \\
132 \\
177 \\
948 \\
502 \\
1,176 \\
51 \\
6\end{array}$ & $\begin{array}{c}2(25 \%) \\
7(5 \%) \\
4(2 \%) \\
84(9 \%) \\
61(12 \%) \\
212(18 \%) \\
24(47 \%) \\
3(50 \%)\end{array}$ & $\begin{array}{c}6(75 \%) \\
125(95 \%) \\
173(98 \%) \\
864(91 \%) \\
441(88 \%) \\
964(82 \%) \\
27(53 \%) \\
3(50 \%)\end{array}$ \\
\hline $\begin{array}{l}\text { Income } \\
\quad<\$ 24 \text { million } \\
\text { \#24-36 million } \\
¥ 36-48 \text { million } \\
¥ 48-60 \text { million } \\
>\$ 60 \text { million }\end{array}$ & $\begin{array}{l}1,669 \\
748 \\
353 \\
156 \\
74\end{array}$ & $\begin{array}{l}200(12 \%) \\
90(12 \%) \\
53(15 \%) \\
25(16 \%) \\
20(27 \%)\end{array}$ & $\begin{array}{c}1,469(88 \%) \\
658(88 \%) \\
300(85 \%) \\
131(84 \%) \\
54(73 \%)\end{array}$ \\
\hline $\begin{array}{l}\text { Political Leanings } \\
\text { Very Progressive } \\
\text { Progressive } \\
\text { Neutral } \\
\text { Conservative } \\
\text { Very Conservative }\end{array}$ & $\begin{array}{c}109 \\
782 \\
1,393 \\
638 \\
78\end{array}$ & $\begin{array}{l}25(23 \%) \\
132(17 \%) \\
151(11 \%) \\
75(12 \%) \\
14(18 \%)\end{array}$ & $\begin{array}{c}84(77 \%) \\
650(83 \%) \\
1,242(89 \%) \\
563(88 \%) \\
64(82 \%)\end{array}$ \\
\hline
\end{tabular}

To test the hypothesis that conflict experience will determine level of trust in government, a multiple variables regression analysis was conducted with control variables of gender, age, education, income, and political ideology (table 6). Variance inflation factors for each variable were calculated to identify whether there was a multicollinearity problem in the multiple variables regression model. Since the highest VIF, for the gender variable, was 1.98 , there is multicollinearity problem. 
Table 6. Results of Multiple Variables Regression of Conflict Experience and Public Trust

\begin{tabular}{|c|c|c|c|c|}
\hline \multirow[b]{2}{*}{ Variables } & \multicolumn{4}{|c|}{ Percentage (\%) } \\
\hline & B & $\begin{array}{l}\text { Standard } \\
\text { Error }\end{array}$ & $\mathbf{t}$ & $\begin{array}{c}\text { Variance } \\
\text { Inflation } \\
\text { Factor }\end{array}$ \\
\hline Constant & 4.36 & .149 & 29.28 & \\
\hline \multicolumn{5}{|l|}{ Control Variables } \\
\hline Male & -.103 & .081 & 5.40 & 1.32 \\
\hline Age & $.018^{\star \star \star}$ & .003 & -1.28 & 1.86 \\
\hline Education ( $\leq$ Middle School) & $-.408^{\star}$ & .161 & -2.54 & 1.98 \\
\hline Education (High School) & -.096 & .099 & -.98 & 1.70 \\
\hline Education (Vocational College) & -.110 & .103 & -1.06 & 1.21 \\
\hline Income (Poor) (W12-24 million) & .196 & .101 & 1.95 & 1.30 \\
\hline Income (Medium) ( $\$ 24-60$ million) & .106 & .094 & 1.13 & 1.75 \\
\hline Income (Rich) ( $\geq \$ 60$ million) & .274 & .243 & 1.13 & 1.15 \\
\hline Very Progressive & $-.633^{\star \star}$ & .192 & -3.29 & 1.05 \\
\hline Progressive & .012 & .087 & .14 & 1.19 \\
\hline Conservative & $.383^{\star \star \star}$ & .095 & 4.04 & 1.22 \\
\hline Very Conservative & .103 & .227 & .46 & 1.05 \\
\hline \multicolumn{5}{|l|}{ Independent Variable } \\
\hline Conflict Experience & $-.943^{\star * \star}$ & .106 & -8.91 & 1.04 \\
\hline $\mathrm{F}$ & \multicolumn{4}{|c|}{$14.05^{\star \star *}$} \\
\hline Adjusted $\mathrm{R}^{2}$ & \multicolumn{4}{|c|}{.058} \\
\hline
\end{tabular}

This regression analysis indicates that if a person experienced a conflict with the government in Korea, the level of his or her trust in government was lower than that of a person who did not $(\beta=-.943, p<.001)$. If we take in to account all of the significant control variables, experience of public conflict emerges as the most powerful predictor of level of public trust in Korea, and so the first hypothesis can be adopted.

The regression analysis also suggests that older and somewhat more conservative people might have a higher level of trust in government, although the correlation is low. Very progressive people showed a lower level of trust in government than neutral people. The negative relationship between conflict experience and public trust in Korea implies that the government or individuals' behavior (or strategy) in conflict management was not effective or satisfactory enough to build trust in government. 


\section{The Impact of Experience of Public Conflict on the Level of Trust in Various} Public Institutions

To test the second hypothesis - people will react in different ways to individual experience of conflict with the government, which in turn will affect their level of public trust in various public institutions - this study used the same survey question to measure trust in the government in the broad sense as shown in table 3Respondents again rated their levels of trust in each institution on a 11-point scale, where 0 is no confidence and 10 is very confident.

Table 7. Results from Multiple Variables Regression of Conflict Experience and Trust in Various Public Institutions in Korea

\begin{tabular}{|c|c|c|c|c|c|}
\hline \multirow[b]{2}{*}{ Variables } & \multicolumn{5}{|c|}{ Trust in } \\
\hline & $\begin{array}{c}\text { Central } \\
\text { Government } \\
\text { Agencies }\end{array}$ & $\begin{array}{l}\text { Local } \\
\text { Government }\end{array}$ & $\begin{array}{l}\text { National } \\
\text { Assembly }\end{array}$ & Courts & $\begin{array}{c}\text { Public } \\
\text { Corporations }\end{array}$ \\
\hline \multirow[t]{2}{*}{ Constant } & 4.31 & 4.48 & 3.76 & 4.84 & 4.96 \\
\hline & \multicolumn{5}{|c|}{ B } \\
\hline \multicolumn{6}{|l|}{ Control Variables } \\
\hline Male & -.036 & -.136 & -.087 & $-.213^{\star \star}$ & $-.214^{\star \star}$ \\
\hline Age & $.018^{* \star *}$ & $.017^{\star \star \star}$ & $.008^{*}$ & $.013^{* \star *}$ & $.014^{\star \star \star}$ \\
\hline Education (£Middle School) & -.294 & .072 & .025 & -.213 & -.122 \\
\hline Education (High School) & -.135 & .045 & .138 & -.170 & -.121 \\
\hline Education (Vocational College) & -.059 & .001 & .114 & -.040 & .031 \\
\hline Income (Poor) (W12-24 million) & .170 & .058 & .026 & .169 & .114 \\
\hline Income (Medium) $¥ 24-60$ million) & .063 & .099 & -.054 & .146 & .163 \\
\hline Income (Rich) ( $\geq \# 60$ million) & .166 & .118 & -.114 & .069 & -.385 \\
\hline Very Progressive & $-.541^{\star \star}$ & $-.385^{*}$ & -.218 & $-.568^{\star \star}$ & -.311 \\
\hline Progressive & -.012 & .024 & .120 & .078 & .035 \\
\hline Conservative & $.402^{\star \star \star}$ & $.191^{*}$ & .154 & $.329^{\star \star \star}$ & $.186^{*}$ \\
\hline Very Conservative & .172 & -.165 & $-.768^{\star \star}$ & -.183 & -.101 \\
\hline $\begin{array}{l}\text { Independent Variable } \\
\text { Conflict Experience }\end{array}$ & $-.882^{\star \star \star}$ & $-.760^{\star \star \star}$ & $-1.01^{\star \star \star}$ & $-.811^{\star \star \star}$ & $-.914^{\star \star \star}$ \\
\hline $\mathrm{F}$ & $12.61^{\star * *}$ & $11.32^{\star \star \star}$ & $9.69^{* \star \star}$ & $10.20^{\star \star \star}$ & $11.95^{\star \star *}$ \\
\hline Adjusted $\mathrm{R}^{2}$ & .052 & .047 & .041 & .043 & .050 \\
\hline
\end{tabular}

${ }^{*} \mathrm{p}<.05{ }^{* *} \mathrm{p}<.01{ }^{* * *} \mathrm{p}<.001$ 
Using the same multiple variables regression model that was used in testing the first hypothesis, this study tested and compared relationships between individual experiences of conflict and levels of trust in different public institutions, including central government agencies, local governments, the national assembly, courts, and public corporations in Korea (table 7).

Table 7 suggests significantly negative relationships between conflict experience and levels of trust in all the various public institutions and degrees of impact of conflict experience are different, supporting the hypothesis that the different ways people react to conflict experience has an impact on their levels of trust in various public institutions. Interestingly, the negative impact of conflict experience was the largest $(B$ $=-1.01)$ for the level of trust in the national assembly and the lowest ( $\beta=-.7 .60)$ for the level of trust in local government. Individual experience of public conflicts lowered the levels of public trust in public corporations and central government agencies more than in courts. Age was the common and significant factor affecting the level of public trust. Income and gender also made a difference in the level of trust in different institutions.

The different impacts of conflict experience on levels of trust in different public institutions may be due to the different characteristics (e.g., frequency, severity, or scope) of public conflicts particular to each public institution. For example, public conflicts that were intensified in politicized public policy making in the national assembly might negatively affect the level of trust in national assembly. Also, conflict experience related to the central government lowered the level of trust in central government agencies more than conflict experience related to local government did.

\section{Impact of Individual Conflict Approaches on the Level of Trust in Government}

To test the third hypothesis about the effect of individual approaches to conflict management on the level of trust in government, this study used a survey question asking which activities in the three years prior to the survey the survey respondent had participated in individually or as representative of an organization when he or she experienced conflict with the government. The question could be answered only by people who had experienced conflict in the prior three years before taking the survey. Out of the 3,000 selected for the survey, only 397 respondents had experienced public conflict in the preceding three years; these 397 selected all the activities they had taken part in among 20 choices (table 8). 
Table 8. Participation Modes of Citizens Who Have Experienced Conflict

\begin{tabular}{l|c}
\hline \multicolumn{1}{c|}{ Participation Mode } & Frequencies \\
\hline lumping it (doing nothing) & $214(37.5 \%)$ \\
attending official presentations for residents & $30(5.3 \%)$ \\
participating in public hearings & $18(3.2 \%)$ \\
participating in an opinion poll & $101(17.7 \%)$ \\
filing a petition via government website & $14(2.5 \%)$ \\
meeting with a mayor or a governor & $6(1.1 \%)$ \\
meeting with a national assembly member & $5(0.9 \%)$ \\
filing a petition with an ombudsman office & $4(0.7 \%)$ \\
requesting a national audit & $2(0.4 \%)$ \\
attending a press conference & $1(0.2 \%)$ \\
voting on a referendum & $43(7.5 \%)$ \\
taking part in a signature campaign & $94(16.5 \%)$ \\
adding signature to a petition recalling elected officials & $6(1.1 \%)$ \\
participating in administrative litigation & $7(1.2 \%)$ \\
holding a one-person demonstration & $3(0.5 \%)$ \\
attending a mass rally & $14(2.5 \%)$ \\
serving on an advisory committee & $2(0.4 \%)$ \\
serving on a citizen jury & $0(0 \%)$ \\
ad-hoc collaborative governance committee & $6(1.1 \%)$ \\
\hline Total & $570(100 \%)$ \\
\hline
\end{tabular}

For a more meaningful statistical analysis, it is necessary to further divide these various individual approaches into a small number of typologies. Five categories of conflict approaches are formulated: lumping it, conventional participation, active participation, rights- and/or power-based approaches, and deliberation. Lumping it means doing nothing. Conventional participation category refers to the case in which an individual participated only in one or more of the three conventional public opinion consultation methods: attending an official presentation for residents, participating in a public hearing, and participating in an opinion poll.

Rights- or/and power-based approaches account for the cases when an individual happened to use any rights-based or power-based approach, such as petitioning an ombudsman office, participating in a signature campaign for recalling an elected official, participating in administrative litigation, or participating in a mass rally. The typology of deliberation includes participation in ad-hoc collaborative governance committees ( individuals who use deliberative strategies may also use rights-based strategies, such as administration litigation). Participation in an ad-hoc collaborative governance committee is rare, but it may be influential in building trust in government. 
The category of active participation covers the cases where an individual used various approaches except rights- and power-based approaches and deliberation. For example, the participation of a citizen who took part in a public hearing or signature campaign, voted in a referendum, or submitted a petition via government website is categorized as active. Consequently, all the different combinations of individual approaches in the sample of 397 people with conflict experience are assigned to one of the five modes of conflict approaches (table 9).

Table 9. Types of Individual Approaches to Public Conflict in the Sample

\begin{tabular}{l|c}
\hline \multicolumn{1}{c|}{ Types of Approaches } & Frequencies \\
\hline lumping It & $214(53.9 \%)$ \\
conventional participation & $41(10.4 \%)$ \\
active participation & $113(28.4 \%)$ \\
rights- and/or power-based approaches & $23(5.8 \%)$ \\
deliberation & $6(1.5 \%)$ \\
\hline Total & 397 \\
\hline
\end{tabular}

Interestingly, it was observed that more than $50 \%$ of Korean people who experienced public conflict in the three years prior to the survey lumped it (table 9). Motivation for lumping it may be different for different people. Some people might not do anything because they trust the government or because they lack power or are frustrated. In any case, just avoiding conflicts may ultimately be unsatisfactory, since they will end up merely accumulating grievances in the long run. On the other hand, not many of the respondents engaged in deliberation through multistakeholder processes or negotiations with governments (1.5\%) (table 9). The reason for this may be that the Korean public is not often presented with the opportunity to participate in negotiation or deliberation with governments as a conflict prevention or resolution mechanism.

To test the hypothesis that rights- and power-based approaches to address public conflict with the government will affect the levels of public trust more negatively than other conflict approaches a multiple variables regression analysis was conducted (table 10). As conflict experience is believed to affect level of public trust negatively in Korea according to the first hypothesis, conflict approaches that people adopted to address their concerns ought to influence levels of public trust, and results from the regression analysis partly support this hypothesis. When people who faced conflicts opted to take a rights- and/or power-based approach, their level of public trust in government was significantly reduced $(\beta=-1.44, p<.01)$, more than in cases of people who just lumped. People who participated actively in using other strategies also 
showed less public trust $(ß=-.709, \mathrm{p}<.05)$ than people who just lumped it.

It is suspected that the level of public trust was reduced with rights- and/or power-based approaches because such approaches are costly, less satisfactory than other approaches, and worsen the relationship with the government. However, it is unknown why people chose rights- and/or power-based approaches, and so that requires further research. In the case of people participating actively using strategies other than rightsor power-based approaches and deliberation via conventional channels of public consultation and/or through voluntary activities, it is likely that those conventional channels and the people's own efforts were not sufficient to resolve conflicts or build trust in government.

Table 10. Results from Multiple Variables Regression of Conflict Approaches and Trust in Government in Korea

\begin{tabular}{|c|c|c|c|c|}
\hline \multirow[b]{2}{*}{ Variables } & \multicolumn{4}{|c|}{ Trust in Government } \\
\hline & b & $\begin{array}{l}\text { Standard } \\
\text { Error }\end{array}$ & $\mathbf{t}$ & $\begin{array}{c}\text { Variance } \\
\text { Inflation } \\
\text { Factor }\end{array}$ \\
\hline Constant & 2.99 & .475 & 6.28 & - \\
\hline $\begin{array}{l}\text { Control Variables } \\
\text { Male } \\
\text { Age } \\
\text { Education (£Middle School) } \\
\text { Education (High School) } \\
\text { Education (Vocational College) } \\
\text { Income (Poor) ( } 1212-24 \text { million) } \\
\text { Income (Medium) ( } \square 24-60 \text { million) } \\
\text { Income (Rich) ( }{ }^{\circ} 60 \text { million) } \\
\text { Very Progressive } \\
\text { Progressive } \\
\text { Conservative } \\
\text { Very Conservative }\end{array}$ & $\begin{array}{c}-.062 \\
.029^{\star \star} \\
.298 \\
.059 \\
-.238 \\
.548 \\
.959^{\star *} \\
1.49^{\star \star} \\
-1.61^{\star *} \\
-.641^{\star} \\
.445 \\
.021\end{array}$ & $\begin{array}{l}.267 \\
.010 \\
.735 \\
.314 \\
.338 \\
.342 \\
.308 \\
.571 \\
.505 \\
.280 \\
.336 \\
.656\end{array}$ & $\begin{array}{c}-.23 \\
2.71 \\
.41 \\
.19 \\
-.70 \\
1.60 \\
3.11 \\
2.62 \\
-3.19 \\
-2.29 \\
1.33 \\
.03\end{array}$ & $\begin{array}{l}1.34 \\
1.34 \\
1.29 \\
1.23 \\
1.12 \\
1.31 \\
1.74 \\
1.34 \\
1.13 \\
1.31 \\
1.30 \\
1.10\end{array}$ \\
\hline $\begin{array}{l}\text { Conflict Approaches } \\
\text { Conventional Participation } \\
\text { Active Participation } \\
\text { Rights and Power Based } \\
\text { Deliberation }\end{array}$ & $\begin{array}{c}.153 \\
-.709^{\star} \\
-1.44^{\star *} \\
-1.27\end{array}$ & $\begin{array}{l}.397 \\
.276 \\
.518 \\
.975\end{array}$ & $\begin{array}{l}0.39 \\
-2.57 \\
-2.77 \\
-1.30\end{array}$ & $\begin{array}{l}1.10 \\
1.16 \\
1.10 \\
1.06\end{array}$ \\
\hline $\begin{array}{l}\mathrm{F} \\
\text { Adjusted } \mathrm{R}^{2}\end{array}$ & & & & \\
\hline
\end{tabular}




\section{Impact of the Level of Trust in Government on Individual Conflict Approaches}

As shown in testing the first and third hypotheses, individual conflict experience with the government and the behaviors people adopt to address their concerns seem to reduce the level of trust in government significantly. To complete the picture of this vicious circle of conflict and trust in Korea, it is necessary to test the fourth hypothesis: that lower levels of public trust will induce more people to adopt rights- and power-based approaches to conflict management.

If people with a lower trust in government are willing to use more adversarial approaches such as rights- or power-based approaches, it is expected that the level of trust in government will be lowered more. When it comes to approaches to dealing with conflict with the government in the future, the 3,000 respondents were asked to select only one among 11 choices (table 11).

Table 11. Approaches to Public Conflict in the Future

\begin{tabular}{l|c}
\hline Types of Individual Approaches & Frequencies \\
\hline lumping it & $1,327(44.2 \%)$ \\
filing a petition & $641(21.4 \%)$ \\
meeting with a national assembly member & $16(0.5 \%)$ \\
taking part in a signature campaign & $492(16.4 \%)$ \\
attending a press conference & $12(0.4 \%)$ \\
participating in administrative litigation & $220(7.3 \%)$ \\
forming an alliance with another group & $87(2.9)$ \\
taking part in a demonstration & $113(3.8 \%)$ \\
negotiating with government & $20(0.7 \%)$ \\
collaborating in multiparty governance & $65(2.2 \%)$ \\
other & $7(0.2 \%)$ \\
\hline Total & \\
\hline
\end{tabular}

To provide a more meaningful statistical analysis, five other types of approach to conflict were generated as dependent variables in testing the fourth hypothesis: lumping it, grievance-lodging activities, rights-based activities, power-based activities, and negotiation. Signing a petition or meeting with a national assembly member to issue a complaint were counted as grievance-lodging activities. Participating in administrative litigation was considered a rights-based activity, while participating in signature campaigns and press conferences, forming an alliance with another group, and taking part in a demonstration were considered power-based activities. Consultation with the 
government or multiparty collaborative governance were treated as instances of negotiation.

Table 12 shows the approaches taken by both citizens with conflict experience and citizens without it. Interestingly, citizens with past conflict experience were willing to adopt more power-based approaches (39.5\%), the rights-based approach (9.4\%), and negotiation $(4.0 \%)$ in the future than citizens without it. Within the group of citizens with past conflict experience, unfortunately, almost $40 \%$ were willing to use power-based approaches to address their concerns in future conflicts. Adding in people who considered the rights-based approach means that almost $50 \%$ of the Korean people rely on power- or rights-based approaches in managing conflict. In addition, $26 \%$ of the people chose to just lump it. Those potential patterns of behaviors of the public in conflict situations imply that the Korean dispute resolution system has been working ineffectively, incurring high social costs, worsening the relationship between the people and governments, and lowering trust among stakeholders and governments.

Table 12. Individual Approaches to Public Conflict by Citizens Who Have and Who Have Not Experienced Conflict

\begin{tabular}{l|c|c}
\hline $\begin{array}{l}\text { Types of Individual } \\
\text { Approaches to Public } \\
\text { Conflict }\end{array}$ & $\begin{array}{c}\text { Citizens Who Have Experienced } \\
\text { Public Conflicts } \\
\text { N=395 (100\%) }\end{array}$ & $\begin{array}{c}\text { Citizens Who Have Not } \\
\text { Experienced Public Conflicts } \\
\mathbf{N = 2 , 5 9 8 ~ ( 1 0 0 \% ) ~}\end{array}$ \\
\hline lumping it & $104(26.3 \%)$ & $1,223(47.1 \%)$ \\
grievances lodging & $82(20.8 \%)$ & $575(22.1 \%)$ \\
rights-based approach & $37(9.4 \%)$ & $183(7.0 \%)$ \\
power-based approach & $156(39.5 \%)$ & $548(21.1 \%)$ \\
negotiation & $16(4.0 \%)$ & $69(2.7 \%)$ \\
\hline
\end{tabular}

In order to test the impact of levels of trust in government on individual approaches to conflict in the future, multiple logistic regression analyses were conducted for each category of individual approach to public conflict (table 13). Marginal effects after logistic regression show that public trust has a positive relationship with the lumping it approach and negative relationships with the rights- and power-based approaches, partly supporting the hypothesis that levels of trust in government will determine individual approaches to public conflict with government. In other words, if the level of trust increases (or decreases) by one unit, then the willingness to use a power-based approach may be decreased (or increased) by $2.2 \%$ and willingness to use a rightsbased approach by $0.5 \%$. Also, if the level of trust increases by one unit, then lumping it will increase by $3.6 \%$. Interestingly, level of education shows a statistically mean- 
ingful influence on approaches to conflict but with opposite correlations between lumping it and rights- and power-based approaches. Citizens with lower education tend to lump it more and use rights- or power-based approaches less.

Table 13. Results (Marginal Effects) from Logistic Regression of Public Trust and Individual Approaches to Future Conflict

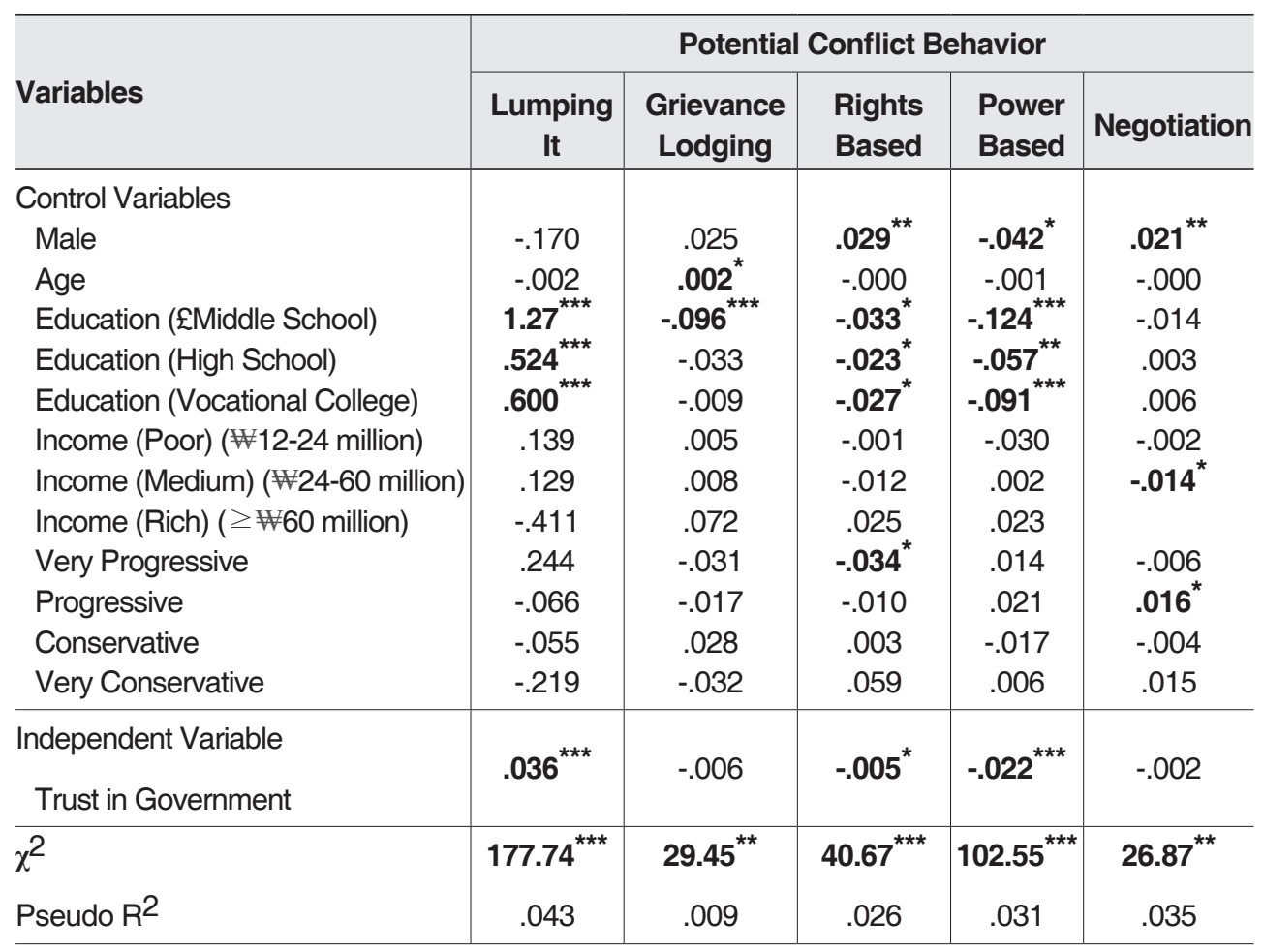

${ }^{*} p<.05{ }^{* \star} p<.01{ }^{* \star *} p<.001$

\section{DISCUSSION AND CONCLUSION}

We cannot completely prevent public conflict from occurring in a society. However, we can manage public conflicts in ways to prevent them from getting so serious that they end up incurring high social costs and reducing trust among stakeholders and in the government. This study has considered whether there is a vicious cycle of public conflict and level of trust in government in Korea. Testing the first, third, and fourth 
hypotheses reveals empirically that public conflict experiences negatively affects the level of trust in government in Korea (the first hypothesis) and that lower levels of trust in government can also lead citizens to adopt less effective approaches to conflict, such as rights- and power-based approaches (the fourth hypothesis), which in turn may lower the level of trust in government (the third hypothesis). Thus, this study concludes that Korea seems to be in a vicious cycle of conflict and public trust.

If the number of public conflicts increases and their severity intensifies, effective conflict management on the part of both the government and the citizens will be critical in rebuilding trust in government. Currently, the use of rights- and power-based approaches seem to be associated with a low level of public trust. It is imperative for the government to think about how to reduce the cases of lumping it and of resorting to rights- or power-based approaches and instead increase reliance on beneficial processes like negotiation and collaborative governance through which stakeholders can build trust. Kim (2014) suggests that despite a history of prolonged, serious public conflict, stakeholders, including government agencies, can build trust among themselves through a collaborative governance mechanism, such as the Shi-Hwa Sustainable Development Committee in Korea.

It is not clear what percentage of public trust derives from public experience of public conflicts and what percentage is accounted for by other determinants, such as integrity and performance of the government. However, it is quite certain that the public's experience of public conflicts is not constructive but detrimental to relationships and that the effect of conflict on public trust is negative, which, in turn, is highly likely to promote more and severe conflicts in the future.

Thus, government efforts to reduce the number and severity of public conflicts through innovative and more effective ways of conflict management may contribute to increasing the level of public trust, and the roles and capacities of public sectors in managing public conflicts will be very important in building public trust.

More in-depth case studies in which researchers trace the source of public trust or distrust following certain conflict management processes would be helpful. It would also be very useful to assess the impact of strategic media, which tends to aggravate conflicts, on the level of trust in government. In addition, apart from the control variables that this study uses, there may be other potential and idiosyncratic variables that may affect public trust only in Korea, such as regional affiliation and profession. Thus, it would be worthwhile to explore those factors as independent variables in future research. If those factors prove to be significant variables that affect public trust in Korea, the argument of this study will be strengthened by controlling those variables too. 


\section{REFERENCES}

Alvarez, R. M., \& J. Brehm. 1998. Speaking in two voices: American equivocation about the Internal Revenue Service. American Journal of Political Science, 42(2): 418-452.

Ansell, C., \& A. Gash. 2008. Collaborative governance in theory and practice. Journal of Public Administration Research and Theory, 18(4): 543-571.

$\mathrm{Bae}, \mathrm{J} .-\mathrm{H} .2013$. 시민의 정부에 대한 평가와 태도. 한국행정논집, 25(4): 1329-1343.

Beierle, T. C., \& Konisky, D. M. 2000. Values, conflict, and trust in participatory environmental planning. Journal of Policy Analysis and Management, 19(4): 587602.

Beierle, T. C., \& Konisky, D. M. 2001. What are we gaining from stakeholder involvement? Observations from environmental planning in the Great Lakes. Environment and Planning C: Government and Policy 19(4): 515-527.

Bouckaert, G., \& Van de Walle, S. 2003. Comparing measures of citizen trust and user satisfaction as indicators of "good governance": Difficulties in linking trust and satisfaction indicators. International Review of Administrative Sciences, 69(4): 329-343.

Bovens, M. 2007. Analyzing and assessing accountability: A conceptual framework. European Law Journal, 13(4): 447-468.

Bovens, M., \& A. Wille. 2008. Deciphering the Dutch drop: Ten explanations for decreasing political trust in the Netherlands. International Review of Administrative Sciences, 74(2): 283-305.

Cho, G.-S., \& Nam, J.-H. 2007. 대통령의 리더십과 정부신뢰: 노무현 대통령 사례를 중심으로. 한국과 국제정치, 23(2): 61-92.

Cho, Y. 2013. 정부신뢰의 선거적 기원: 이명박 집권 중반 시기를 중심으로. 한국과 국제정치, 29(3): 121-153.

Christensen, T., \& P. Laegried. 2005. Trust in government: The relative importance of service satisfaction, political factors, and demography. Public Performance and Management Review, 28(4): 487-511.

Chung, Y. H., \& Ko, S. J. 2015. Social conflict index and economic growth: Evidence from a cross-section of 7 countries. Public Health and Welfare Forum, March: 44-55.

Citrin, J. 1974. The political relevance of trust in government. American Political Science Review, 68(3): 973-988.

Costintino, C. A., \& Merchant, C. S. 1996. Designing conflict management systems: A guide to creating productive and healthy organizations. San Francisco: JosseyBass. 
Dalton, R. 2004. Democratic challenges, democratic choices: The erosion of political support in advanced industrial democracies. Oxford: Oxford University Press.

Dewey, J. 2012. The public and its problems. State College: Penn State University Press.

Dovidio, J. F., S. L. Gaertner, K. Kawakami, \& Hodson, G. 2002. Why can't we just get along? Interpersonal biases and interracial distrust. Cultural Diversity and Ethnic Minority Psychology, 8(2): 88-102.

Eidelson, R. J., \& Eidelson, J. I. 2003. Dangerous ideas: Five beliefs that propel groups toward conflict. American Psychologist, 58(3): 182-192.

Elchardus, M. 2002. De dramademocratie. Tielt, Belgium: Lannoo.

Erber, R., \& Lau, R. R. 1990. Political cynicism revisited: An information-processing reconciliation of policy-based and incumbency-based interpretations of changes in trust in government. American Journal of Political Science, 34(1): 236-253.

Fehr, E., \& Schmidt, K. M. 1999. A theory of fairness, competition, and cooperation. Quarterly Journal of Economics, 114(3): 817-868.

Feldman, S. 1983. The measurement and meaning of trust in government. Political Methodology, 9(3): 341-354.

Fukuyama, F. 1995. Trust: The social virtues and the creation of prosperity. New York: Free Press.

Han, N.-D. 2014. 공공갈등관리제도 실태분석 및 개선방안. 사업평가현안분석 제53 호. 국회예산정책처.

Hibbing, J. R., \& Theiss-Morse, E. 2001. Process preferences and American politics: What the people want government to be. American Political Science Review, 95(1): 145-153.

Honeyman, C., Goh, B. C., \& Kelly, L. 2004. Skill is not enough: Seeking connectedness and authority in mediation. Negotiation Journal, 20(4): 489-511.

Hood, C. 2006. Transparency in historical perspective. In C. Hood \& D. Heald (eds.), Transparency: The key to better governance? (pp. 3-23). Oxford: Oxford University Press.

Huseby, B. M. 2000. Government performance and political support: A study of how evaluations of economic performance, social policy and environmental protection influence the popular assessments of the political system. Trondheim: Institutt for sosiologi og statsvitenskap.

Hutchison, M. L., \& Johnson, K. 2011. Capacity to trust? Institutional capacity, conflict, and political trust in Africa, 2000-2005. Journal of Peace Research, 48(6): 732-752.

Imperial, M. 2005. Using collaboration as a governance strategy: Lessons from six watershed management programs. Administration and Society, 37(3): 281-320. 
Inglehart, R. 1999. Postmodernization Erodes Respect for Authority, But Increase Support for democracy. In P. Norris (ed.), Critical citizens: Global support for democratic government (pp. 236-256). Oxford: Oxford University Press.

Jeon, D.-S., Kwon, I-.W., \& Ho, K. 2013. 정부신뢰에 대한 연구: 대통령에 대한 신뢰 와 정부정책에 대한 평가 비교를 중심으로. 한국정책학회보, 22(2): 181-206.

Kelman, H. 2005. Building trust among enemies: The central challenge for international conflict resolution. International Journal of Intercultural Relations, 29(6): 639-650.

Kim, B., \& Yi, K.-S. 2009. 정치경제적 관점에서 본 정부신뢰의 영향요인: 이명박정 부에 대한 국민인식을 중심으로. 한국행정논집, 21(3): 893-914.

Kim, B., \& Yi, K.-S. 2013. 대통령신뢰와 행정부신뢰의 영향요인 분석. 한국사회와 행정연구, 24(2): 541-566.

Kim, D. Y. 2014. Governance reform in Korea: Reinventing a participatory, deliberative, and collaborative governance. In S. H. Kim (ed.), Citizen participation, transparency, and public trust in government: Participatory budgeting in local governments of Korea (pp. 5-34). Research Monograph 2014-03. Seoul: KDI.

Kim, D. Y. 2014. Transformation of countervailing power in collaborative governance: A case study of the Shi-Hwa Sustainable Development Committee. Korean Journal of Policy Studies, 29(3): 53 77.

Kim, J., \& Shim, J.-S. 2011. 투명성이 원자력발전소 운영기관에 대한 신뢰를 매개 로 정책수용성에 미치는 영향. 정책분석평가학회보, 21(3): 149-178.

Kim, S. 2010. Public trust in government in Japan and South Korea: Does the rise of critical citizens matter? Public Administration Review, 70(5): 801-810.

Kim, S.-D. 2009. 사회경제적 지위와 정치적 성향이 국가기관 불신에 미치는 영향: 정부정책불신의 매개효과. 한국사회학, 43(2): 25-54.

Kim, Y. W., \& Cha, M.-S. 2001. Public dispute resolution in Korea. KRIHS Special Report 1.

Kum, H., \& Baek, S. 2010. 정치적 이념, 정부신뢰 그리고 정책지지. 행정논총, 48(4): 201-228.

Lee, S.-I. 2013. 정부신뢰에 대한 정치적 성과와 경제적 성과의 효과 비교와 관계성 탐색: 성별 차이를 중심으로. 정부학연구, 19(2): 195-239.

Lee, Y. 2014. 정부기관 및 사회기관 신뢰에 대한 국민과 공무원의 인식 차이에 관한 비교 연구. 사회과학논집, 45(1): 25-58.

Lee, Y.-S. 2013. 무사안일이 정부신뢰에 미치는 영향. 정부와 정책, 6(1): 29-47.

Lewicki, R. J., \& Wiethoff, C. 2000. Trust, trust development, and trust repair. In. M. Deutsch \& P. T. Coleman (eds.), The handbook of conflict resolution: Theory and practice (pp. 86-107). San Francisco: Jossey-Bass.

Mayer, R. C., Davis, J. H., \& Schoorman, F. 1995. An integrative model of organiza- 
tional trust. Academy of Management Review, 20(3): 709-734.

Mishler, W., \& Rose, R. 2001. Political support for incomplete democracies. International Political Science Review, 22(4): 303-320.

Moon, B. B., \& Park, G. 2014. 정책갈등 관리에 있어 정부 신뢰와 불신의 역할: 담배 값 인상 정책을 중심으로. Journal of Public Relations, 18(3): 216-240.

Murdock, B., Wiessner, C., \& Sexton, K. 2005. Stakeholder participation in voluntary environmental agreements: Analysis of 10 Project XL case studies. Science, Technology and Human Values, 30(2): 223-250.

Newton, K. 2006. May the weak force be with you: The power of the mass media in modern politics. European Journal of Political Research, 45(2): 209-234.

OECD. 2010. Making reform happen: Lessons from OECD countries. Paris: OECD.

OECD. 2015. Governance at a glance, 2015. Paris: OECD.

OECD. 2017. Trust and public policy: How better governance can help rebuild public trust. Paris: OECD.

Park, C.-M., \& Bae, J. H. 2011. 정부신뢰의 원인: 정책결과, 과정 및 산출. 정부학연 구, 17(2): 117-142.

Park, H.-B., \& Lee, Y. R. 2012. 시민문화와 정부정책이 정부신뢰에 미치는 영향. 한 국행정논집, 24(4): 913-936.

Park, J. 2009. Korea's social conflict and its economic cost. Issue Report 07-09. Samsung Economic Research Institute.

Park, M. H. 2010. Development and application of a cross-national indicator for economic and social development. Korean Economic Forum, 2(4): 115-131 (in Korean).

Pharr, S., \& Putnam, R. D. 2000. Disaffected democracies: What's troubling the trilateral countries? Princeton, NJ: Princeton University Press.

Przeworski, A., Alvarez, M., Cheibub, J. A., \& Limongi, F. 1996. What makes democracies endure? Journal of Democracy, 7(1): 39-55.

Putnam, R. P. 1993. Making democracy work: Civic traditions in modern Italy. Princeton, NJ: Princeton University Press.

Simpson, J. A. 2007. Foundations of interpersonal trust. In A. W. Kruglanski \& E. T. Higgins (eds.), Social psychology: Handbook of basic principles (pp.). New York: Guilford Press.

Susskind, L., \& Field, P. 1996. Dealing with an angry public: The mutual gains approach to resolving disputes. New York: Free Press.

Ury, W., Brett, J., \& Goldberg, S. 1988. Getting disputes resolved: Designing systems to cut the costs of conflict. San Francisco: Jossey-Bass.

Van de Walle, S., \& Bouckaert, G. 2003. Public service performance and trust in government: the problem of causality. International Journal of Public Administra- 
tion, 26(8-9): 891-913.

Vangen, S., \& Huxham, C. 2003. Nurturing collaborative relations: Building trust in interorganizational collaboration. Journal of Applied Behavioral Science, 39(1): 5-31.

Weech-Maldonado, R., \& Merrill, S. 2000. Building Partnerships with the Community: Lessons from the Camden Health Improvement Learning Collaborative. Journal of Healthcare Management, 45: 189 205.

Yang, K.-M., \& Park, T. H. 2007. 의사, 약사의 정책과정 참여가 보건복지부에 대한 신뢰에 미치는 영향. 한국행정학보, 41(4): 357-385.

Yarn, D. H. 1999. Conflict. In Dictionary of Conflict Resolution. San Francisco: Jossey-Bass.

Zaller, J. R. 1996. The myth of massive media impact revived: New support for a discredited idea. In D. C. Mutz, P. M. Sniderman, \& R. M. Brody (eds.), Political persuasion and attitude change (pp. 17-78). Chicago: University of Chicago Press. 
